\title{
Contaminated sediment resuspension induces shifts in phytoplankton structure and function in a eutrophic Mediterranean lagoon
}

\author{
C. Lafabrie ${ }^{(1,4), \star}$, A.S. Hlaili(2), C. Leboulanger ${ }^{(1)}$, I. Tarhouni( ${ }^{(2)}$, \\ H.B. Othman ${ }^{(1,2)}$, N. Mzoughi ${ }^{(3)}$, L. Chouba ${ }^{(3)}$, O. Pringault ${ }^{(1,4)}$ \\ Received February 13, 2013 \\ Revised June 7, 2013 \\ Accepted June 13, 2013
}

\section{ABSTRACT}

Key-words: sediment resuspension, chemical contaminants, nutrients, phytoplankton, mediterranean lagoon

\begin{abstract}
The combined effects of contaminants and nutrients released from sediment into the water column during resuspension-mixing events were assessed on the phytoplankton composition and productivity in the anthropized lagoon of Bizerte (Tunisia, Mediterranean Sea). During a 4-day experiment, phytoplankton was exposed in in situ immersed microcosms to sediment elutriates (untreated: El and sterilized: S-EI), prepared from a sediment resuspension simulation process, and its responses were evaluated and compared with controls. Elutriate addition resulted in an enrichment of the water with contaminants (mix of metals and PAHs) and nutrients $\left(\mathrm{NO}_{2}^{-}, \mathrm{NH}_{4}^{+}, \mathrm{PO}_{4}^{3-}\right.$, Si $\left.(\mathrm{OH})_{4}\right)$. The resulting contaminant enrichment was similar among treatments, but the nutrient enrichment was slightly higher in the S-El treatment than in the El treatment. Our results show that both elutriates strongly stimulated phytoplankton growth. They also show that the S-El-induced shifts in the phytoplankton community composition slightly enhanced the species diversity, whereas the El did not seem to have any effect on the phytoplankton community composition. In addition, our results show that the net production was stimulated by both elutriate treatments, after $24 \mathrm{~h}$ and $48 \mathrm{~h}$ of exposure to S-El and El. During the first hours, both elutriates induced a prompt increase in respiration, resulting in a temporary (2-3 days) switch of the systems from net autotrophy $(P: R>1)$ to net heterotrophy $(P: R<1)$. Hence in anthropized coastal environments, sediment resuspensions are likely to have significant effects on the structure and productivity of pelagic primary producers, and thereby on carbon transfer throughout food webs.
\end{abstract}

\section{RÉSUMÉ}

La remise en suspension de sédiments contaminés induit des changements dans la structure et le fonctionnement du phytoplancton dans une lagune méditerranéenne eutrophe

\footnotetext{
Mots-clés : remise en suspension de sédiment,

Les effets combinés des contaminants et des nutriments relargués dans la colonne d'eau par le sédiment, lors de phénomènes de remise en suspension de sédiment, ont été évalués sur la composition et la productivité du phytoplancton dans la lagune anthropisée de Bizerte (Tunisie, Méditerranée).

(1) UMR 5119 ECOSYM, Université Montpellier 2, 34095 Montpellier, France

(2) Laboratoire de Cytologie Végétale et Phytoplanctonologie, Faculté des Sciences de Bizerte, 7021 Zarzouna, Tunisia

(3) Institut National des Sciences et Technologies de la Mer, La Goulette, 2060 Tunis, Tunisia

(4) Present address: JEAI (IRD) ECOBIZ, Faculté des Sciences de Bizerte, 7021 Zarzouna, Tunisia

^ Corresponding author: celine.lafabrie@ird.fr
} 
contaminants chimiques, nutriments, phytoplancton, lagunes méditerranéennes
Pendant 4 jours, le phytoplancton a été exposé, au sein de microcosmes disposés in situ, à des élutriats de sédiment (non stérilisé : El, et stérilisé : S-El) préparés à partir de simulations de remise en suspension de sédiment, et ses réponses ont été évaluées et comparées à des contrôles. L'ajout d'élutriat a entraîné un enrichissement de l'eau en contaminants (mélange de métaux-traces et HAPs) et nutriments $\left(\mathrm{NO}_{2}^{-}, \mathrm{NH}_{4}^{+}, \mathrm{PO}_{4}^{3-}, \mathrm{Si}(\mathrm{OH})_{4}\right)$. L'enrichissement en contaminants était similaire dans les microcosmes traités avec El et $\mathrm{S}-\mathrm{El}$; par contre, l'enrichissement nutritif était légèrement supérieur dans les microcosmes traités avec S-El que dans ceux traités avec El. Les résultats obtenus mettent en évidence une forte stimulation de la croissance phytoplanctonique par les deux élutriats. Ils indiquent également que le S-El a engendré des modifications au niveau de la composition de la communauté phytoplanctonique, en augmentant légèrement la diversité spécifique, alors qu'El ne semble pas avoir eu d'effet sur la structure phytoplanctonique. De plus, les résultats obtenus mettent en évidence une stimulation de la production nette par les deux élutriats, après $24 \mathrm{~h}$ d'exposition pour S-El et $48 \mathrm{~h}$ pour El. Ils indiquent par ailleurs que les deux élutriats ont provoqué une augmentation rapide et importante de la respiration au cours des premières heures d'exposition, conduisant les systèmes à une hétérotrophie nette $(P: R<1)$ temporaire (2-3 jours). Cette étude montre ainsi que, dans les environnements côtiers anthropisés, les phénomènes de remise en suspension de sédiment peuvent engendrer des modifications de la structure et de la productivité des producteurs primaires pélagiques, et, par conséquent, modifier le transfert de carbone au sein des réseaux trophiques.

\section{INTRODUCTION}

With increasing human settlement in coastal zones (Martinez et al., 2007), marine coastal ecosystems are facing multiple anthropogenic threats (Halpern et al., 2008). Owing to the significant number of goods (e.g., commercially important seafood) and services (e.g., nutrient cycling) that depend on these important ecosystems (Costanza et al., 1997; Barbier et al., 2011), assessing and predicting the ecological consequences of the combined effects of co-occurring stressors on these systems is thus essential. These steps are prerequisites to effectively targeted management plans in coastal areas. Yet to date, research investigating several stressors remains scarce (see the review of Crain et al., 2008; O'Gorman et al., 2012), probably because such work is highly challenging. The combined impact of two or more stressors may not always be additive (equal to the sum of individual effects), and interactive effects may also occur, either synergistic (greater than the sum of individual effects) or antagonistic (less than the sum of individual effects; Folt et al., 1999; Crain et al., 2008; Darling and Côté, 2008), which further complicates the task.

Due to their shallowness, coastal waters can experience frequent sediment resuspension through storms and wind-driven waves in sandy areas (Liu and Huang, 2009; Roberts, 2012). In anthropized areas, such mixing events can induce release of contaminants and nutrients from the sediment into the water column, and generate contaminant and nutrient water enrichment (Morin and Morse, 1999; Cantwell et al., 2002; Kalnejais et al., 2010). Sediment resuspension can thus result in pulsed exposures of pelagic communities to complex mixtures of contaminants and nutrients. To date, the ecological consequences of resuspension of contaminated and nutrient-rich sediments are unclear (Roberts, 2012), although a few studies report that nutrients and contaminants may have opposing main effects, interacting antagonistically (i.e., the beneficial impact of nutrients could overcompensate for the detrimental impact of contaminants; Crain et al., 2008). Phytoplankton, the autotrophic component on which depend crucial ecosystem functions, appears particularly sensitive to contaminants and nutrients in combination. However, contrasting results are found in the literature. For example, Riedel et al. (2003) report an inhibition of phytoplankton growth after exposure to contaminants (mix of trace metals) and nutrients in combination, but Lawrence et al. (2004) 


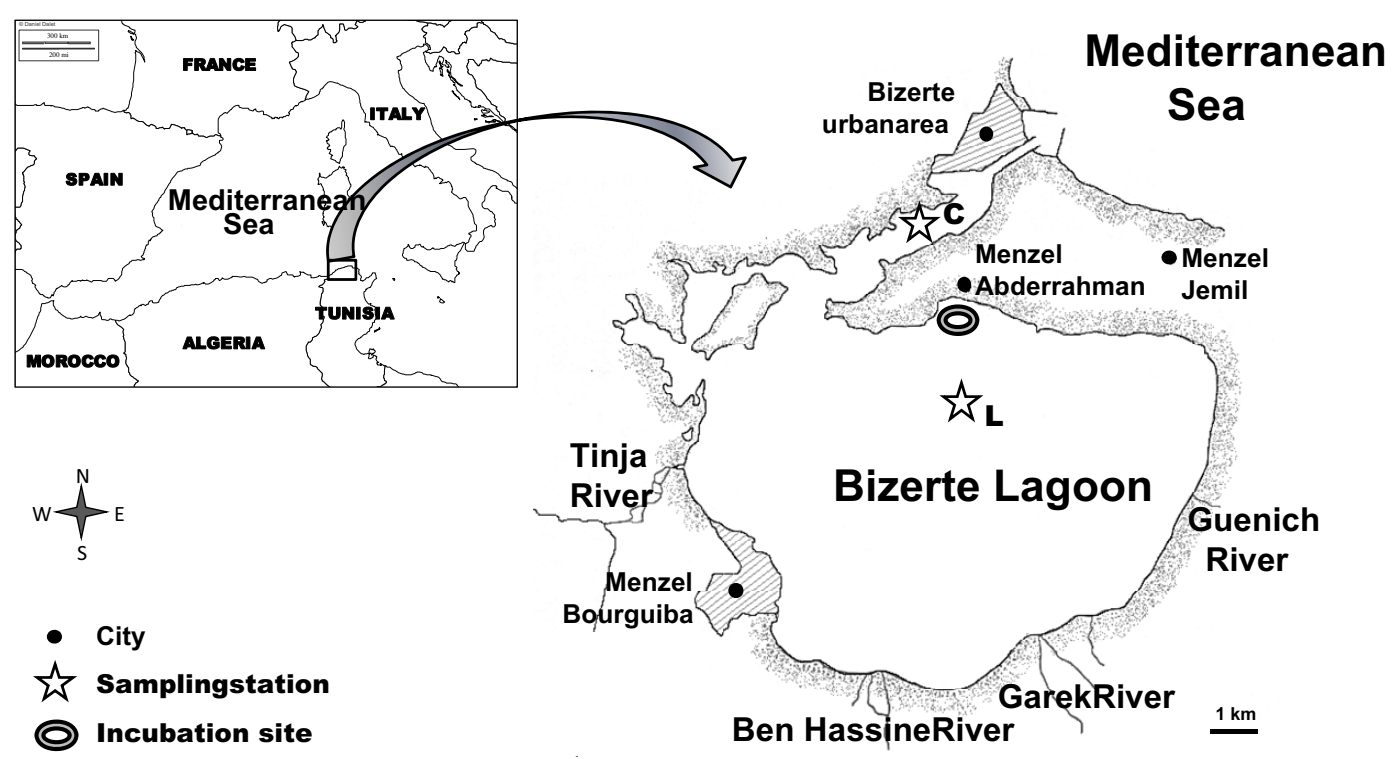

\section{Figure 1}

Sampling stations (C : Channel ; L : Lagoon) and incubation site in the Bizerte lagoon (Tunisia, Mediterranean Sea).

and Sundback et al. (2010) observed growth stimulation after a wind-mixing event in a shallow bay and after exposure to a contaminant-nutrient mixture, respectively. In the light of current scientific knowledge, no clear conclusions can therefore be drawn regarding the impact of nutrients and contaminants in combination on phytoplankton, and so no effective management plans can be proposed for the coastal areas where these two chemical stressors co-occur.

The Bizerte lagoon is one of the most economically important coastal areas in Tunisia. It sustains large populations of planktivorous fish and shellfish (mussels, oysters and clams), and has been exploited for fishing activities for several centuries, and mussel farming more recently (Harzallah, 2002). In recent decades human settlement and industrial activities have been rapidly increasing all around the lagoon, and are now seriously threatening the water quality, the ecological equilibrium of the lagoon, and the dependent resources (Béjaoui et al., 2008). Recent work conducted in the Bizerte lagoon has revealed moderate-to-high chemical contamination of the sediment (e.g., Mzoughi et al., 2005; Ben Said et al., 2010), and high nutrient enrichment of the water (e.g., Sakka Hlaili et al., 2007; Sahraoui et al., 2012). The primary objective of our study was to assess the combined effects of the contaminants and nutrients that can be released from the sediment into the water column, during resuspension mixing-events, on the community composition and the productivity of phytoplankton in the anthropized lagoon of Bizerte. We also examined the combined effects of contaminants and nutrients on the autotrophic-heterotrophic coupling. These were carried out through in situ microcosm experiments.

\section{MATERIAL AND METHODS}

\section{> STUDY AREA}

The Bizerte lagoon is located in the south-western Mediterranean Sea, on the northern coast of Tunisia $\left(37^{\circ} 8^{\prime}-37^{\circ} 14^{\prime} \mathrm{N}, 9^{\circ} 46-9^{\circ} 56^{\prime} \mathrm{E}\right.$; Figure 1). Its surface area is about $128 \mathrm{~km}^{2}$ and its depth averages $7 \mathrm{~m}$ (Béjaoui et al., 2008). The most frequent and strongest winds are north-westerly, with a frequency of 200 days.year ${ }^{-1}$ and an average speed of $6-8 \mathrm{~m} \cdot \mathrm{s}^{-1}$ (Ouakad, 2007). In the shallowest areas of the lagoon, the highest magnitude wind-mixing events can thus supply enough energy to resuspend the superficial layer of the sediment. 


\section{> SEDIMENT ELUTRIATE PREPARATION AND CHEMICAL ANALYSES}

Water and sediment were sampled in the Bizerte channel (Station C in Figure 1), a densely populated area exposed to intensive maritime traffic and grouping large cement works and oil refineries. High levels of trace metals and polycyclic aromatic hydrocarbons have been previously reported at this site (Ben Said et al., 2010).

Water was collected at the surface with a bucket, and immediately $200 \mu \mathrm{m}$ filtered (mesh) to remove the largest fragments and organisms. Sediment was collected using a Van Veen grab, and sieved ( $2 \mathrm{~mm}$ mesh) to eliminate fauna and plant fragments.

Sediment elutriate was prepared from the method described in Geffard et al. (2002). Sediment was stirred in water (ratio 1:4) for $8 \mathrm{~h}$ to mimic resuspension mixing. After an $8 \mathrm{~h}$ settling period, the overlying water was siphoned off and filtered $(200 \mu \mathrm{m})$ to obtain the elutriate solution (El). One part of this elutriate was autoclaved $\left(20 \mathrm{~min}\right.$ at $\left.120^{\circ} \mathrm{C}\right)$ to obtain a sterilized elutriate solution (S-El) in which the activity of the microorganisms potentially present $<200 \mu \mathrm{m}$ was inhibited.

Contaminant analyses of sediment and elutriates were performed at the Laboratory of Rouen (COFRAC accredited laboratory, France; http://www.laborouen.com). They included the following chemical groups: trace metals (8), organotins (3), polycyclic aromatic hydrocarbons (PAHs, 16) and polychlorinated biphenyls (PCBs, 7).

Nutrient analyses $\left(\mathrm{NO}_{3}^{-}, \mathrm{NO}_{2}^{-}, \mathrm{NH}_{4}^{+}, \mathrm{PO}_{4}^{3-}, \mathrm{Si}(\mathrm{OH})_{4}\right)$ of elutriates were carried out by spectrophotometry (6305 spectrophotometer, JENWAY), according to Aminot and Chaussepied (1983).

\section{> WATER SAMPLING AND ANALYSES}

The water sample was collected at Station $L$ (see Figure 1), a low-contaminated area in the north of the lagoon (Trabelsi and Driss, 2005; Ben Said et al., 2010). The sampling was performed at depth $6 \mathrm{~m}$ using a Hydro-Bios water sampler (Kiel-Holtenau, Germany). After collection, the water sample was immediately filtered on a $200 \mu \mathrm{m}$ mesh to eliminate large debris and mesozooplankton.

Contaminant and nutrient concentrations were determined on sub-samples, using the same methods as for elutriate analyses (see precedent section). Sub-samples were also used for chlorophyll a ( $\mathrm{Chl}$ ) and phytoplankton taxonomic analyses (see the methods used below, in section "Chl a analysis" and "Phytoplankton identification and counting").

\section{> IN SITU MICROCOSM EXPERIMENT}

The experiment lasted from March 27 to 31, 2012. Nine $5 \mathrm{~L}$ glass bottles (Schott-Duran) were used as microcosms to perform three treatments (Control, El and S-El) in triplicate. To each microcosm was added $3 \mathrm{~L}$ of $200 \mu \mathrm{m}$ filtered water (water collected at Station $\mathrm{L}$ ). Then $1 \mathrm{~L}$ of sterilized water, El and S-El was added to each control, El and S-El microcosms, respectively. All microcosms thus contained $1 \mathrm{~L}$ of air ( $20 \%$ of the total volume), allowing gas exchanges to occur (de la Broise and Palenik, 2007).

The theoretical contaminant and nutrient concentrations of the El and S-El supplemented microcosms at the beginning of the experiment were calculated from the concentrations measured in the initial water, the $\mathrm{El}$ and the $\mathrm{S}-\mathrm{El}$, and from the different corresponding volumes added to the microcosms (when one concentration value was below the detection limit, it was considered as half the detection limit value). These theoretical concentrations enabled us to calculate contaminant and nutrient enrichment factors (EF; EF $=$ [treated microcosm $]_{\text {theoretical }} /$ [initial water]).

The nine microcosms were incubated in situ at depth $50 \mathrm{~cm}$ (Figure 1) so that the phytoplankton was placed in the natural conditions of temperature and irradiance. The water temperature 
was recorded over the course of the experiment (temperature data logger HOBO ProV2, Onset), and the light irradiance was measured every day at midday (LI-250A light meter fitted with a LI-192 underwater quantum sensor, LI-COR).

At five time points $(t=0,24,48,72$ and $96 \mathrm{~h})$, samples were collected $(1000,250,600$, 250 and $1000 \mathrm{~mL}$, respectively) from each microcosm. Before the last sampling, the remaining volume within each microcosm thus represented $50 \%$ of the initial volume, ensuring that samplings had no effects on phytoplankton. The analyses carried out on the collected samples are detailed below. Salinity and $\mathrm{pH}$ of samples were measured at each sampling time using a multiparameter probe (Multi 1970i, WTW).

\section{$>$ CHL A ANALYSIS}

Sub-samples of known volumes were filtered through Whatman GF/F filters and stored at $-80{ }^{\circ} \mathrm{C}$ until analysis. Pigments were extracted using $90 \%$ acetone by soaking the filters overnight at $4^{\circ} \mathrm{C}$. Chl a concentrations were determined according to Ritchie (2008), from the readings of the 630,647, 664 and $750 \mathrm{~nm}$ absorbance values on the absorption spectra obtained by spectrophotometry (spectrophotometer AL-800, Aqualytic, FRG).

\section{> PHYTOPLANKTON IDENTIFICATION AND COUNTING}

For phytoplankton identification and counting, sub-samples were preserved with acidic Lugol solution and stored at $4{ }^{\circ} \mathrm{C}$ in the dark until microscopic examination. After a 24-30 h settling period in a $50 \mathrm{~mL}$ chamber slide, phytoplankton cells were identified to the lowest possible taxonomic level and counted under a 100x objective, using a CESI inverted microscope (Utermöhl, 1958; Lund et al., 1958). A minimum of 200 cells per sample were counted when possible.

\section{>MEASUREMENTS OF THE PRODUCTION AND RESPIRATION}

Net production (NP) and dark respiration $\left(R_{\text {dark }}\right)$ were determined by the oxygen light-dark method (see e.g., Pringault et al., 2007) from $6 \mathrm{~h}$ incubations at the laboratory (thermostatically controlled incubator, AquaLytic). Sub-samples were poured into $1000 \mu \mathrm{L}$ glass chambers (Unisense, Denmark) hermetically closed with glass stoppers, and incubated at $\pm 1{ }^{\circ} \mathrm{C}$ in situ temperature. Samples were gently mixed using magnetic stirbars. Dissolved oxygen levels were measured with a Clark-type oxygen microelectrode (Unisense, Denmark) inserted into the chambers through the capillary hole of the glass stoppers. Light incubations were made by exposing samples to ca. $120 \mu \mathrm{mol} \cdot$ photons $\cdot \mathrm{m}^{-2} \cdot \mathrm{s}^{-1}$ (value corresponding to the average irradiance observed in situ at depth approx. $5 \mathrm{~m}$ ). Gross primary production (GPP) was calculated from the NP and $R_{\text {dark }}$ values (GPP $=\left|R_{\text {dark }}\right|+N P$ ).

The $P: R$ ratios were determined from the GPP and $R$ daily rates calculated from the GPP and $R$ hourly rates, respectively. A light period of $12 \mathrm{~h}$ was considered for the calculation of the GPP daily rates, and $R_{\text {light }}$ was assumed to be equivalent to $R_{\text {dark }}$ for the calculation of the $R$ daily rates (Pringault et al., 2007).

\section{> STATISTICAL ANALYSES}

Differences in variables among treatments (fixed factor, 3 levels: control, El, and S-El) and sampling times (fixed factor, 5 levels: $0,24 \mathrm{~h}, 48 \mathrm{~h}, 72 \mathrm{~h}$, and $96 \mathrm{~h}$ ) were investigated with a two-way factorial analysis of variance (ANOVA). When ANOVA revealed significant differences, Tukey's HSD post hoc comparison tests were performed to determine where significant differences occurred (STATISTICA ${ }^{\text {TM }}$ software, StatSoft). The Shannon index $H$ (calculated using natural log transformed data) was used to detect any phytoplankton diversity 
change (MVSP software, Kovach Computing Service, Anglesey, Wales, UK). Correspondence analysis was performed from the relative species abundances to detect any phytoplankton composition change (MVSP software); before analysis, the relative species abundances were transformed (arcsine square-root transformation) to meet the assumptions required by the analysis (Legendre and Legendre, 2012).

\section{RESULTS}

\section{>ENVIRONMENTAL CONDITIONS OF THE EXPERIMENT}

The water temperature in the incubation site ranged from 16 to $21^{\circ} \mathrm{C}$ over the course of the experiment. The mean light irradiance reaching the microcosms was around $1750 \mu \mathrm{mol} \cdot$ photons $\cdot \mathrm{m}^{-2} \cdot \mathrm{s}^{-1}$ at midday.

The salinity and $\mathrm{pH}$ values were similar among microcosms and throughout the experiment ( $\approx 33$ psu and 8 , respectively).

\section{> CONTAMINANT LEVELS}

Contaminant concentrations are shown in Table I. All the elements investigated were detected in the sediment, with the exception of PCBs. In the initial water sample, only some trace metals ( $\mathrm{Cd}, \mathrm{Cu}, \mathrm{Hg}, \mathrm{Ni}, \mathrm{Pb}$, and $\mathrm{Zn}$ ) and one $\mathrm{PAH}$ compound (Phe) were found above the detection limits of the instruments. Elutriates exhibited similar levels of trace metal and $\mathrm{PAH}$ contamination, and no organotin and PCB contamination.

For four trace metals (As, Cr, Ni, Zn) and seven PAHs (Nap, Flt, Chry, BbF, BaP, BghiP, Ind), EFs exceeded 1 (Table I). The metalloid As exhibited the highest EFs (5.2 and 5.8, for El and S-EI microcosms, respectively; Table I). Overall, El and S-EI microcosms exhibited similar level of contaminant enrichment (Table I).

\section{> NUTRIENT LEVELS}

Nutrient concentrations are shown in Table II. They were higher in elutriates than in the initial water. Comparing the two elutriates, with the exception of $\mathrm{NH}_{4}^{+}$, which was detected in similar concentrations, the S-El seemed overall to exhibit higher nutrient levels than the El, although the significance of these differences was not statistically tested, as each result corresponds to a single analysis.

For all nutrients, the EF was greater than 1 (Table II). Overall, nutrient enrichment was higher in S-El than in El microcosms (Table II), ranging from $1.1\left(\mathrm{NO}_{3}^{-}\right.$, El microcosms) to $7.2\left(\mathrm{Si}(\mathrm{OH})_{4}\right.$, S-El microcosms).

\section{> CHL A CONCENTRATIONS}

In the initial water, the Chl a concentration was $4.6 \pm 1.1 \mu \mathrm{g} \cdot \mathrm{L}^{-1}$.

At both the beginning of the experiment $\left(t_{0}\right)$ and $t_{0+48 \mathrm{~h}}$, no significant difference was found among treatments for $\mathrm{Chl}$ a levels $(P \geqslant 0.05$; Figure 2). By contrast, at the end of the experiment $\left(t_{0+96 h}\right), \mathrm{Chl}$ a concentrations were significantly higher in El and S-El microcosms $\left(17.9 \pm 1.5\right.$ and $24.3 \pm 1.3 \mu \mathrm{g} \cdot \mathrm{L}^{-1}$, respectively) than in control microcosms $\left(8.4 \pm 1.1 \mu \mathrm{g} \cdot \mathrm{L}^{-1}\right.$; $p<0.05)$.

No significant difference was found for $\mathrm{Chl}$ a concentrations over time in control microcosms $(p \geqslant 0.05)$, but significant differences were found in El and S-El microcosms ([Chl a]t $t_{0}<$ [Chla] $t_{0+96 h}, p<0.05$; Figure 2). 
C. Lafabrie et al.: Knowl. Managt. Aquatic Ecosyst. (2013) 410, 05

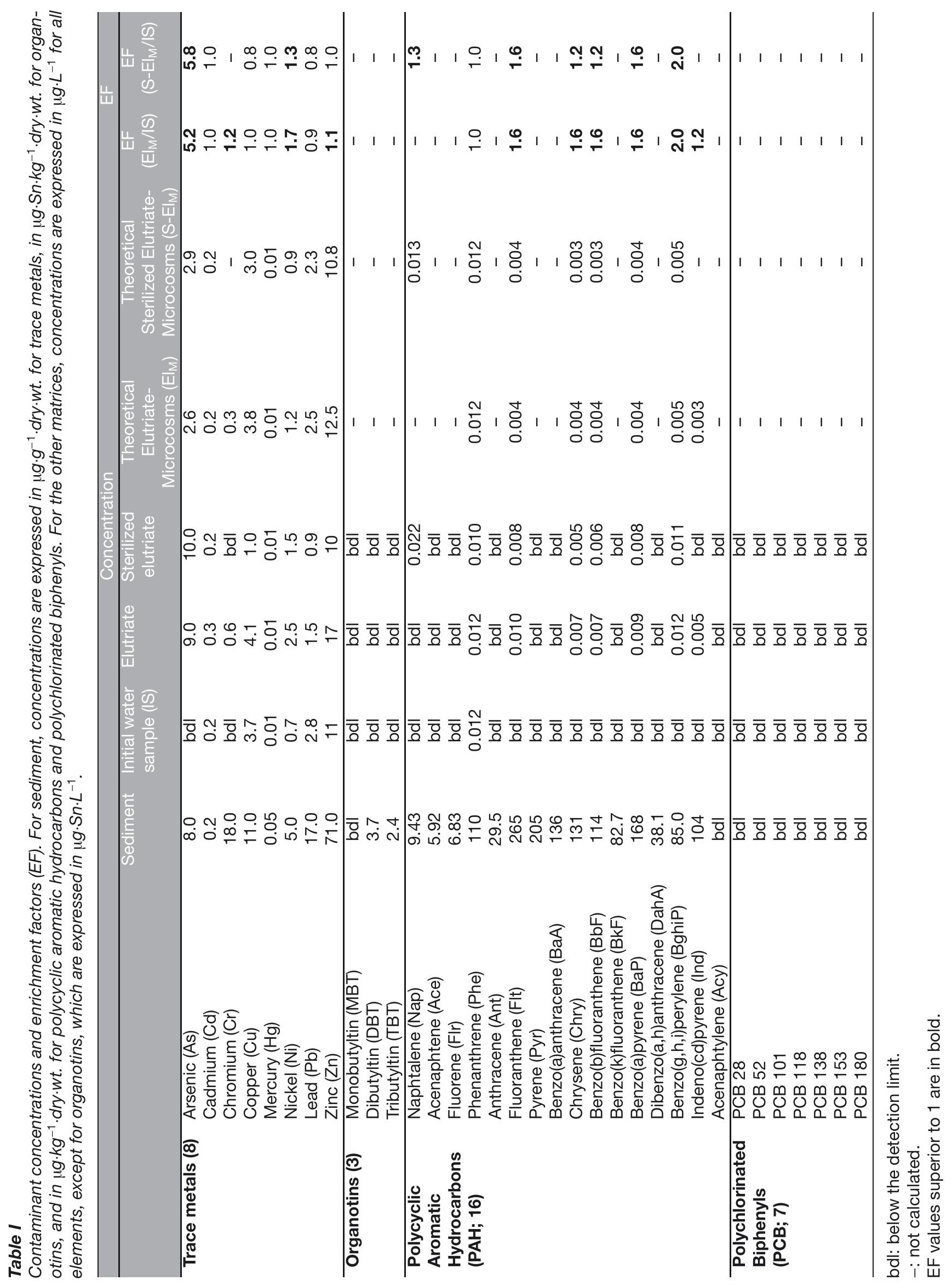


Table II

Nutrient concentrations (in $\mu \mathrm{mol} \cdot \mathrm{L}^{-1}$ ) and enrichment factors (EF).

\begin{tabular}{|c|c|c|c|c|c|c|c|}
\hline & \multicolumn{5}{|c|}{ Concentration } & \multicolumn{2}{|c|}{ EF } \\
\hline & $\begin{array}{l}\text { Initial water } \\
\text { sample (IS) }\end{array}$ & Elutriate & $\begin{array}{l}\text { Sterilized } \\
\text { Elutriate }\end{array}$ & $\begin{array}{c}\text { Theoretical } \\
\text { Elutriate- } \\
\text { Microcosms (E/M) }\end{array}$ & $\begin{array}{l}\text { Theoretical } \\
\text { Sterilized Elutriate- } \\
\text { Microcosms (S-El })\end{array}$ & $\begin{array}{c}E F \\
\left(\left.E\right|_{M} / I S\right)\end{array}$ & $\begin{array}{c}\text { EF } \\
\left(\mathrm{S}-\left.\mathrm{E}\right|_{M} / \mathrm{IS}\right)\end{array}$ \\
\hline $\mathrm{NO}_{3}^{-}$ & 2.99 & 3.61 & 5.07 & 3.15 & 3.51 & 1.1 & 1.2 \\
\hline $\mathrm{NO}_{2}^{-}$ & 0.04 & 0.62 & 0.99 & 0.19 & 0.28 & 4.6 & 7.0 \\
\hline $\mathrm{NH}_{4}^{+}$ & 22.0 & 457.7 & 419.3 & 130.9 & 121.3 & 6.0 & 5.5 \\
\hline $\mathrm{PO}_{4}^{3-}$ & 0.39 & 3.44 & 3.68 & 1.15 & 1.21 & 2.9 & 3.1 \\
\hline $\mathrm{Si}(\mathrm{OH})_{4}$ & 2.00 & 4.50 & 51.61 & 2.63 & 14.40 & 1.3 & 7.2 \\
\hline
\end{tabular}

EF values superior to 1 are in bold.

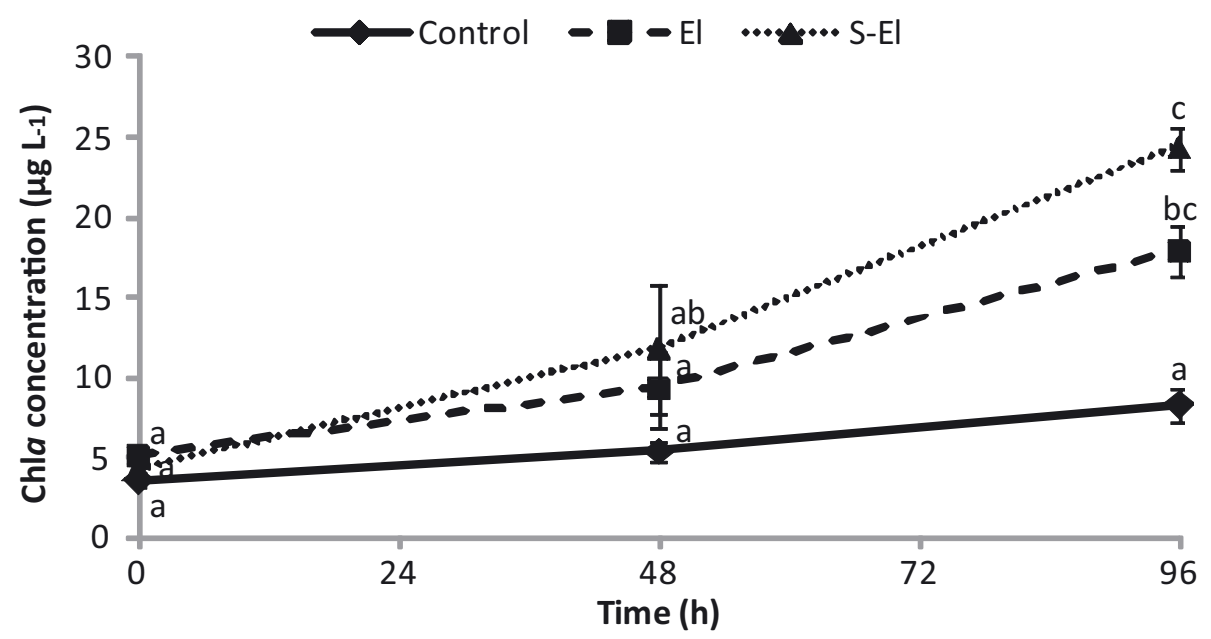

\section{Figure 2}

Chl a concentrations (mean $\pm S E$ in $\mu g \cdot L^{-1}, n=3$ ) in control, elutriate (El) and sterilized elutriate (S-El) microcosms, over time. Means sharing the same letter do not significantly differ $(p \geqslant 0.05)$.

\section{> PHYTOPLANKTON COMMUNITY COMPOSITION}

The initial phytoplankton community was dominated by Diatomophyceae ( $80 \%$, Figure 3$)$, which represented $2.6 \times 10^{6}$ cells. $\mathrm{L}^{-1}$. Chaetoceros was the most abundant genus, followed by Dactyliosolen ( $80 \%$ and $14 \%$ of total Diatomophyceae, respectively). The Shannon index $H$ was $2.59 \pm 0.12$.

At the end of the experiment $\left(t_{0+96 h}\right)$, Diatomophyceae were still dominant in all the microcosms; however, their relative contribution was lower than in the initial water 63,54 and $48 \%$, in control, El and S-El microcosms, respectively; Figure 3). Chaetoceros was still a numerically important genus, but with the exception of S-El microcosms, its relative contribution to Diatomophyceae was lower than that of Dactyliosolen (Chaetoceros and Dactyliosolen relative contribution, respectively $36 \%$ and $55 \%$ in control, $18 \%$ and $70 \%$ in El, and $47 \%$ and $46 \%$ in S-El microcosms). The other main taxonomic groups were Prasinophyceae (control: 12\%; El: 20\%; S-El: 16\%) and flagellates (control: 14\%; El: 10\%; S-El: 13\%, Figure 3). In S-El microcosms, Prymnesiophyceae also formed an important group (13\%, Figure 3). Regarding the overall diversity, the $H$ index was significantly higher in S-El microcosms $(2.83 \pm 0.02)$ than in El and control microcosms $(2.64 \pm 0.03$ and $2.42 \pm 0.03$, respectively, $p<0.10)$.

The correspondence analysis, of which the two main axes explained $68 \%$ of the observed variances, revealed marked changes between the initial and final phytoplankton composition (Figure 4). It also showed that the final community composition in S-El microcosms differed slightly from that in control and El microcosms (Figure 4). Dactyliosolen and Chaetoceros species may have been mainly responsible for these differences as Dactyliosolen appeared 

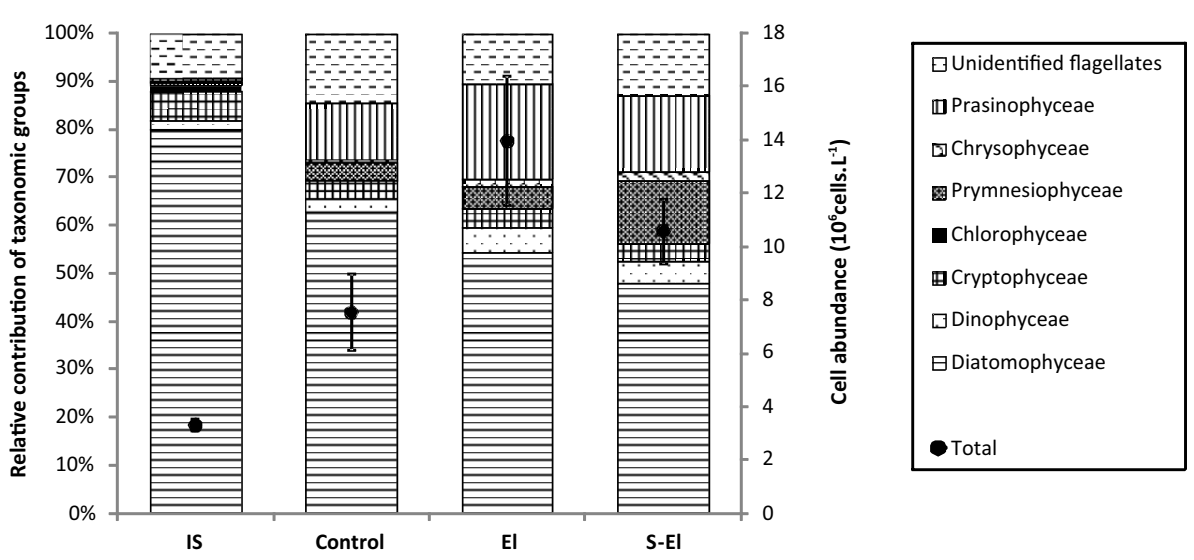

\section{Figure 3}

Contribution of the various taxonomic groups to the total phytoplankton (in percent; represented by bars) and total cell abundance (mean $\pm S E$ in $10^{6} \mathrm{cells} \cdot \mathrm{L}^{-1}$; represented by points), in the initial sample (IS) and the different microcosms at the end of the experiment (Control ; El : elutriate treated ; S-EI : sterilized-elutriate treated).

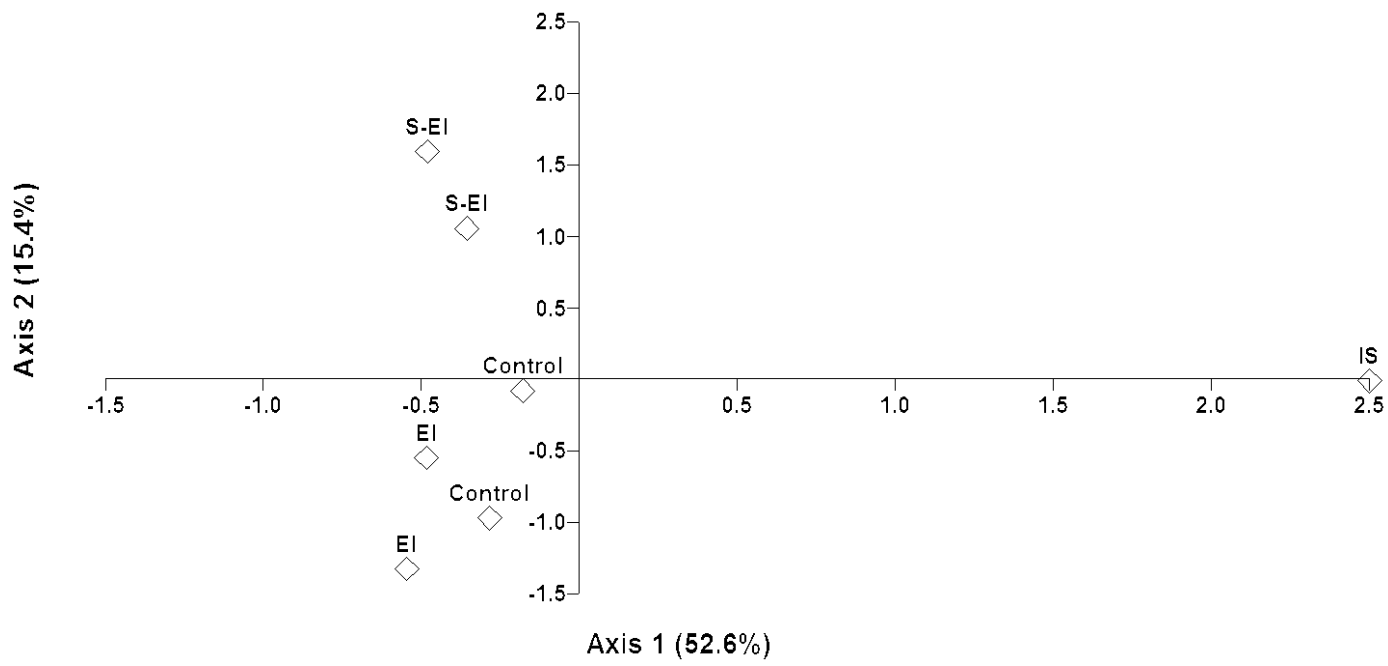

\section{Figure 4}

Correspondence analysis scatter plot obtained from the relative contributions of the identified taxa to the total phytoplankton (IS : initial sample; Control : control microcosms at the end of the experiment ; El : elutriate treated microcosms at the end of the experiment ; S-El : sterilized-elutriate treated microcosms at the end of the experiment).

particularly closely associated with control and El microcosms, and Chaetoceros with S-EI ones (data not shown).

\section{> COMMUNITY PRODUCTION AND RESPIRATION}

As production and respiration were calculated from $6 \mathrm{~h}$ measurements, the $t_{0}$ values allowed the characterization of these parameters very shortly after elutriate exposure: both metabolic activities differed among microcosms as early as the first hours of the experiment (Figure 5). Considering the overall experimental period, GPP, $R_{\text {dark }}$ and NP significantly differed among microcosms; they increased in the following order: Control $<$ El $<$ S-El $(p<0.05)$. In all the microcosms, particularly in the El and S-El microcosms, GPP and NP increased overall with time, while $R_{\text {dark }}$ increased overall until $t_{0+48 \mathrm{~h}}$ and then decreased (Figure 5).

From GPP values and Chl a concentrations, the specific phytoplankton activity was calculated (specific GPP = GPP / [Chl a]). Considering the total experimental period, it was significantly 

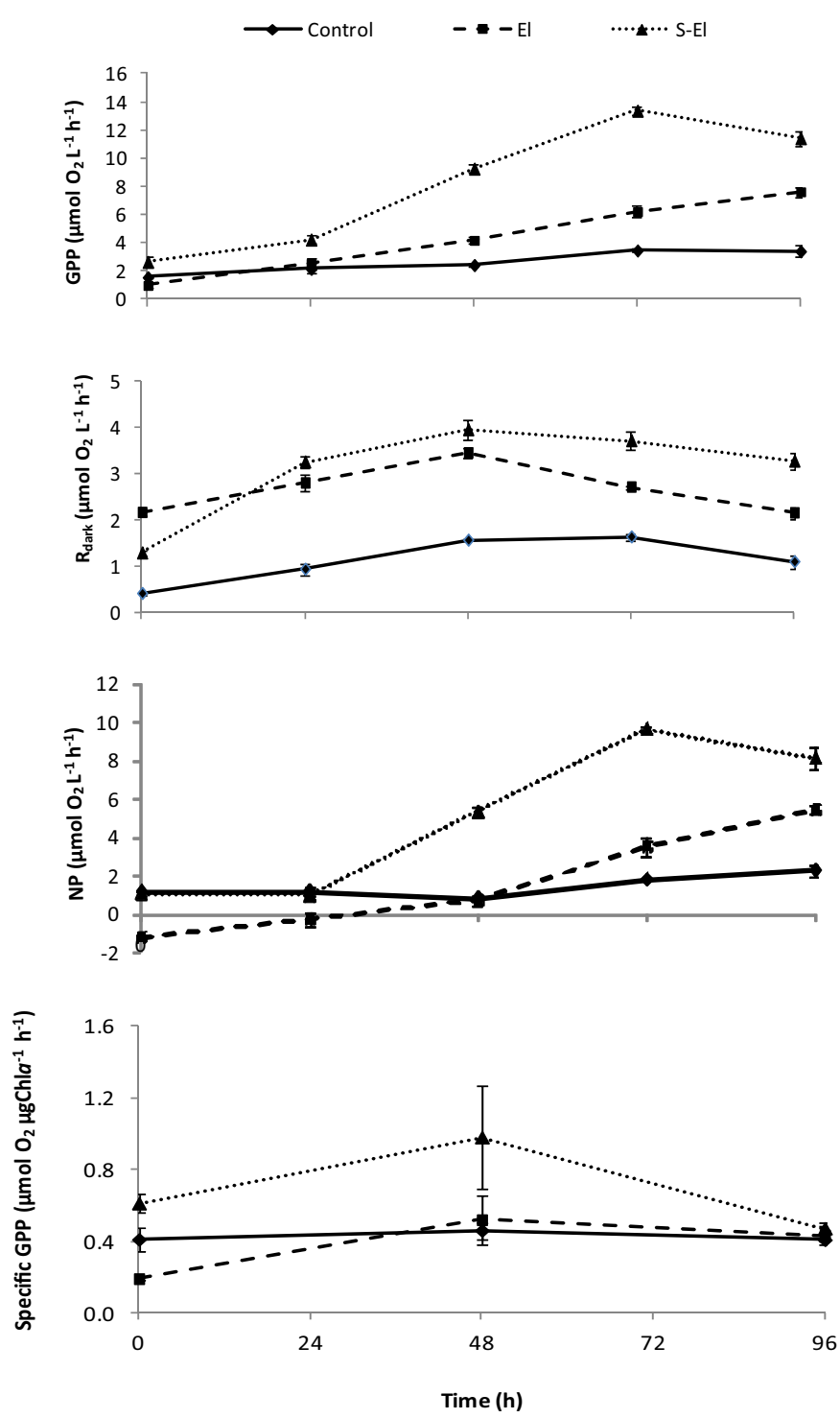

\section{Figure 5}

Gross primary production (GPP), dark respiration (Rdark) and net production (NP) expressed in umol $\mathrm{O}_{2} \cdot L^{-1} \cdot h^{-1}$ (mean \pm S.E.), and specific phytoplankton activity (specific GPP) expressed in $\mu \mathrm{mol} \mathrm{O}_{2} \cdot \mu \mathrm{g} C h \mathrm{l}$ $a^{-1} \cdot h^{-1}$ (mean \pm S.E.) ; in control, elutriate (EI), and sterilized elutriate (S-EI) microcosms, over time.

higher in S-El microcosms than in El and control microcosms $(p<0.05)$. It varied from $0.19 \pm$ 0.01 (Control at $t_{0}$ ) to $0.98 \pm 0.29$ (S-El at $\left.t_{0+48 \mathrm{~h}}\right) \mu \mathrm{mol} \mathrm{O} 2 \cdot \mu \mathrm{g} \cdot \mathrm{Chl}^{-1} \cdot \mathrm{h}^{-1}$ (Figure 5).

The $P: R$ ratio was $>1$ in control microcosms at all time points, except at $t_{0+48 h}$ (Figure 6). In S-El and El microcosms, it switched from $<1$ to $>1$ values, at $t_{0+48 \mathrm{~h}}$ and $t_{0+72 \mathrm{~h}}$, respectively (Figure 6). Except at the end of the experiment $\left(t_{0+96 h}\right)$, the $P: R$ ratio was significantly higher in S-El than in El microcosms at all time points (Figure 6).

\section{DISCUSSION}

\section{> ELUTRIATE-INDUCED CONTAMINANT AND NUTRIENT ENRICHMENT}

The sediment from the Bizerte lagoon exhibited a low-to-moderate trace metal contamination compared with the levels reported in the literature (see concentrations reported for paralic and marine sedimentary environments in Accornero et al., 2008), and a high PAH contamination 


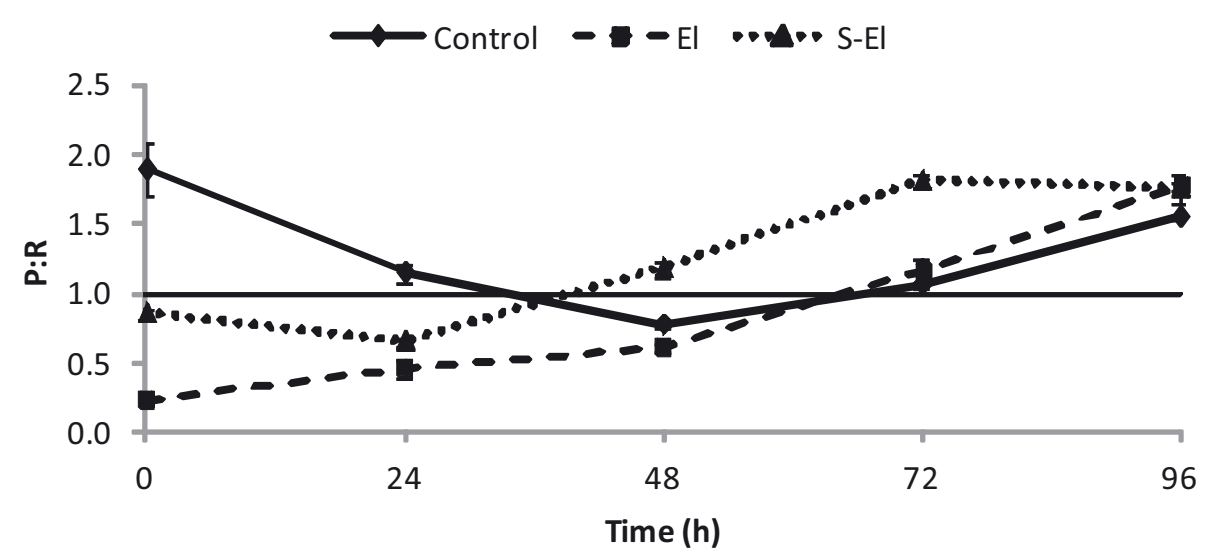

Figure 6

$P: R$ ratios (mean $\pm S . E$.$) in control, elutriate (E I)$ and sterilized elutriate (S-El) microcosms, over time.

according to the levels determined by Baumard et al. (1998; $\Sigma$ PAHs $=1490 \mu \mathrm{g} \cdot \mathrm{kg}^{-1} \cdot \mathrm{dry} \cdot \mathrm{wt}$.). By contrast, it displayed only a low organotin contamination, and no PCB contamination. Previous work reported moderate-to-high levels of trace metals, PAHs and organotins (Yoshida et al., 2002; Mzoughi et al., 2005; Trabelsi and Driss, 2005; Ben Said et al., 2010), and low levels of PCBs (Derouiche et al., 2004) in the sediment of the Bizerte lagoon.

The sediment resuspension simulating process resulted in metal- and $\mathrm{PAH}$-enriched elutriates. Contaminant concentrations of both elutriates were quite similar, further underlining that autoclaving may not have any effect on contaminant levels and "quality" (Day et al., 1995) and thus meets ecotoxicological test requirements (Trevors, 1996). Both elutriate-treated microcosms thus exhibited similar trace metal (As, $\mathrm{Cr}, \mathrm{Ni}, \mathrm{Zn}$ ) and $\mathrm{PAH}$ (Nap, Flt, Chry, BbF, $\mathrm{BaP}, \mathrm{BghiP}$, Ind) enrichments, with As displaying the highest enrichment factor $\left[\mathrm{EF}\left(E \mathrm{I}_{\mathrm{M}} / \mathrm{IS}\right)=\right.$ 5.2 and $E F\left(S-E I_{M} / I S\right)=5.8$; Table I]. Phytoplankton communities were therefore exposed to similar chemical contaminations within El and S-El microcosms. The sediment resuspension simulation process also resulted in nutrient-enriched elutriates. Nutrient concentrations were slightly higher overall in S-El than in El microcosms, which is probably linked to the autoclaving process (see Anderson and Magdoff, 2005). $\mathrm{NO}_{2}^{-}, \mathrm{NH}_{4}^{+}$, and $\mathrm{Si}(\mathrm{OH})_{4}$ were found to display the highest enrichment factors (Table II). Hence in summary, phytoplankton was exposed to a similar contamination pressure within both the El and the S-EI microcosms, but to a slightly higher nutrient enrichment in S-El microcosms than in El microcosms.

\section{> ELUTRIATE EFFECTS ON PHYTOPLANKTON GROWTH}

Both elutriates enhanced phytoplankton growth, resulting in final Chl a concentrations that were twice and three times higher in El and S-El microcosms, respectively, than in control microcosms. From the time course of $\mathrm{Chl}$ a levels, the net growth rate of phytoplankton was estimated to be $0.33 \mathrm{~d}^{-1}$ in control microcosms, and 0.63 and $1.16 \mathrm{~d}^{-1}$ in El and S-El microcosms, respectively. The growth stimulation that was induced by S-El was thus higher than that induced by El, although the differences were not significant. These results suggest that nutrients counteract the possible harmful effects of contaminants on phytoplankton.

Such a phytoplankton growth stimulation effect has also been observed after a wind-mixing event in a shallow subtropical bay in Florida (Lawrence et al., 2004). The strong increases in $\mathrm{NH}_{4}^{+}$and $\mathrm{PO}_{4}^{3-}$ concentrations in the water column were identified as the main causes of this effect (Lawrence et al., 2004). However, other studies have reported a decrease in the total phytoplankton biomass after exposure to contaminants (mix of trace elements) and nutrients in combination (e.g., Riedel et al., 2003). The responses of phytoplankton to contaminants and nutrients in combination may thus depend on threshold levels above which these elements become toxic. 
In addition, compared with controls, elutriate-treated microcosms were slightly enriched with essential metal-micronutrients ( $\mathrm{Ni}$ in both elutriate treatments, and $\mathrm{Zn}$ in the El treatment; Table I). Unlike non-essential trace metals (e.g., As, Cd, Hg), essential metal-micronutrients are involved in protein structure stabilization, facilitate electron transfer reactions and/or catalyse enzymatic reactions (Torres et al., 2008). For example, Zn plays key roles in photosynthetic electron transport within thylakoids (Raven et al., 1999). However, even though some trace metals are essential for metabolic and biological processes, they may also induce adverse effects above threshold levels. For example, Chakraborty et al. (2010) found that $\mathrm{Co}, \mathrm{Ni}, \mathrm{Cu}$ and $\mathrm{Zn}$ could enhance $\mathrm{Chl}$ a biomass up to certain threshold levels and have opposite effects at higher levels (e.g., threshold levels for $\mathrm{Ni}$ and $\mathrm{Zn}$, respectively: 58.7 and $32.7 \mu \mathrm{g} \cdot \mathrm{L}^{-1}$ ). Therefore, the growth increases induced by elutriates could also result from a stimulation by the essential metal-micronutrients $\mathrm{Ni}$ (concentration range in elutriate-treated microcosms: 0.9-1.2 $\mu \mathrm{g} \cdot \mathrm{L}^{-1}$ ) and $\mathrm{Zn}$ (concentration in El microcosm: $12.5 \mu \mathrm{g} \cdot \mathrm{L}^{-1}$; Table I).

\section{> ELUTRIATE EFFECTS ON PHYTOPLANKTON COMMUNITY COMPOSITION}

The phytoplankton sampled in March in the Bizerte lagoon was dominated by Diatomophyceae, as previously reported (see spring data in e.g., Sakka Hlaili et al., 2007; Sahraoui et al., 2009). Both elutriate treatments induced a slight reduction in the relative contribution of Diatomophyceae to the phytoplankton community. Riedel et al. (2003) also reported a decrease in the contribution of Diatomophyceae to phytoplankton exposed to contaminants (mix of trace elements) and nutrients in combination. Diatomophyceae species thus appear particularly sensitive to combined exposure to contaminants and nutrients. This finding is further supported by the study of Mucha et al. (2003), which demonstrated a growth inhibition of the diatom Phaeodactylum tricornutum after exposure to sediment elutriates, whereas the growth of two other microalgae, the coccolithophore Emiliana huxleyi and the green alga Dunaliella minuta, was stimulated. High ammonia concentration was identified as one of the main causes of the $P$. tricornutum growth inhibition. Negative correlations between the growth of a diatom species (Skeletonema costatum) and the ammonia levels of an elutriate solution were reported by Cheung et al. (1997), underlining the possible importance of ammonia in the phytoplankton community structuring. In our study, the elutriate-induced $\mathrm{NH}_{4}^{+}$enrichment was high $\left[E F\left(E I_{M} / I S\right)=6.0\right.$ and $\left.E F\left(S-E I_{M} / I S\right)=5.5\right]$; communities were exposed to $\mathrm{NH}_{4}^{+}$concentrations above $100 \mu \mathrm{mol} \cdot \mathrm{L}^{-1}$ in El as in S-El microcosms (Table II). The decrease in the Diatomophyceae contribution to the community in treated microcosms could therefore be partly caused by the high $\mathrm{NH}_{4}^{+}$levels of both elutriates, despite a strong $\mathrm{Si}(\mathrm{OH})_{4}$ enrichment in S-El microcosms.

In addition, as indicated by the correspondence analysis, S-El appeared to induce more marked shifts within the community structure than El. This may be linked to the slightly higher species diversity of the community exposed to S-EI $(H=2.83 \pm 0.02)$ than that exposed to $\mathrm{El}$ $(H=2.64 \pm 0.03)$. Unlike that of Diatomophyceae, Prymnesiophyceae abundance seemed to be enhanced by S-El, since its contribution to total phytoplankton at the end of the experiment was around three times higher in S-El microcosms than in control and El microcosms. Additionally, the Diatomophyceae exposed to S-El were co-dominated by Chaetoceros (47\%) and Dactyliosolen (46\%) species, whereas Dactyliosolen were dominant in control (55\%) and El $(70 \%)$ microcosms. For similar contaminant levels, slight increases of nutrient supply may thus have enhanced the diversity of the phytoplankton community.

\section{> ELUTRIATE EFFECTS ON THE METABOLIC ACTIVITIES OF THE MICROBIAL COMMUNITY, AND ON THE AUTOTROPHIC-HETEROTROPHIC BALANCE}

The effects of elutriate treatments on the GPP and $R_{\text {dark }}$ occurred as early as the first hours of exposure. Overall, we found that both elutriates induced a stimulation of the GPP and $R_{\text {dark. }}$ 
The S-El, however, induced a higher stimulation than the El. The resulting NP was also found to be stimulated by both elutriate treatments, after $24 \mathrm{~h}$ and $48 \mathrm{~h}$ of exposure to the S-El and the El, respectively. The specific phytoplankton activity was significantly higher in S-El microcosms than in El and control microcosms throughout the experiment. This indicates that the phytoplankton communities in S-El microcosms were more physiologically efficient than in the other treatments. An increase in the specific phytoplankton activity, together with slight structural changes, have been previously reported in a mesocosm experiment for communities exposed to a mix of nutrients with a contaminant (the PAH pyrene; Hjorth et al., 2008). The $P: R$ ratio gives information on the "trophic state" of a system: $P: R>1$ indicates a net autotrophy state, whereas $P: R<1$ indicates a net heterotrophy state (Dodds and Cole, 2007). In our study, the $P: R$ ratios indicate that the treated microcosms were net heterotrophic during the first day or days of exposure, whereas the control microcosms were net autotrophic. Interestingly, the shift to net heterotrophy of the treated microcosms occurred very quickly (within a few hours), as shown by the $t_{0}$ measurements (i.e., effects within the first $6 \mathrm{~h}$ of exposure, see section "Community production and respiration"). These shifts of the productionrespiration balance after elutriate exposure suggest that the transfer of carbon between the autotrophic and heterotrophic compartments may be affected after wind-mixing events. Previous field-based studies also observed the driving of systems towards heterotrophy after sediment resuspension events (Cotner et al., 2000; Lawrence et al., 2004). Similarly, some laboratory experiments showed a reduction of the $P$ :Rratio after a trace metal exposure, reduction of the $P: R$ ratio that resulted in a bacterially dominated heterotrophic system (Nayar et al., 2004; Rochelle-Newall et al., 2008). These findings suggest that shallow anthropized systems may rapidly switch from being a carbon source for the atmosphere to a carbon sink on sediment resuspension, which may thus result in a decrease in carbon transfer towards higher trophic levels. However, it is noteworthy that our study showed that this shift toward heterotrophy was transient, as the system became net autotrophic after a few days of elutriate exposure, suggesting a relative resilience of the system. The same trend was observed by Lawrence et al. (2004). These authors reported that the sudden increase in net heterotrophy observed after a wind event reverted to net autotrophy within a few days.

For control and S-El microcosms, significant correlations were found between GPP and $R_{\text {dark }}$ (Control: $r=0.685, p<0.05$; S-El: $r=0.714, p<0.05$ ), suggesting an apparent coupling between the autotrophic and heterotrophic compartments (cf. Pringault et al., 2009). By contrast, no significant correlation between GPP and $R_{\text {dark }}$ was found for El microcosms, indicating an apparent decoupling between the two compartments. The dependence of heterotrophs on phytoplankton exudates could thus have been lower in El microcosms than in $\mathrm{S}-\mathrm{El}$ microcosms. One reason for this may be that the autoclaving process, by altering the organic matter composition (e.g., destruction of polysaccharide structures; Berns et al., 2008), could have decreased the bioavailability of the sediment-released organic matter in S-El microcosms. Furthermore, the sediment resuspension simulating process may have induced the release of benthic microorganisms into the water. In S-El microcosms, these microorganisms were inactivated through the autoclaving process. The presence of metabolically active benthic heterotrophs and autotrophs in the El microcosms could thus have modified the autotrophic-heterotrophic coupling.

\section{CONCLUSIONS}

Here we present the effects of sediment resuspension on the composition and productivity of phytoplankton in an anthropized Mediterranean lagoon. We show that although sediment resuspension induces release of toxic compounds into the water, it can strongly stimulate phytoplankton growth. The potential adverse effects of the released contaminants thus seem to be counteracted by the nutrients that are also released into the water during such sediment resuspension. We also show that sediment resuspension can moderately modify the phytoplankton community composition. Diatomophyceae species appear particularly sensitive. Additionally, we show that sediment resuspension can induce marked changes in the net 
productivity of the system. In the very short term (during the first hours of the resuspension), it may strongly increase the respiration, bringing the system to a temporary net heterotrophy, before strongly enhancing the net productivity. Our findings therefore suggest that in anthropized coastal environments, sediment resuspension events, inducing release into the water column of mixtures of contaminants and nutrients, can have significant effects on the structure and productivity of pelagic primary producers, and thereby on the carbon transfer throughout food webs.

\section{ACKNOWLEDGEMENTS}

This research was funded by the AIRD (Agence Inter-établissements de Recherche pour le Développement; JEAI ECOBIZ project) and the University of Montpellier 2 (MICROBIZ project). We thank the ISPA (Institut Supérieur de Pêche et d'Aquaculture) staff from Zarzouna (Tunisia) for their help and assistance with field sample collection. We also thank M. Meddeb and I. Sahraoui from the FSB (Faculté des Sciences de Bizerte) for their significant help with field sampling and laboratory analyses. Finally, we thank the two anonymous reviewers for their critical and constructive comments on an earlier version of this manuscript.

\section{REFERENCES}

Accornero A., Gnerre R. and Manfra L., 2008. Sediment concentrations of trace metals in the Berre lagoon (France): an assessment of contamination. Arch. Environ. Con. Tox., 54, 372-385.

Aminot A. and Chaussepied M., 1983. Manuel des analyses chimiques en milieu marin, Centre national pour l'exploitation des océans, Brest, $395 \mathrm{p}$.

Anderson B.H. and Magdoff F.R., 2005. Autoclaving soil samples affects algal-available phosphorus. J. Environ. Qual., 34, 1958-1963.

Barbier E.B., Hacker S.D., Kennedy C., Koch E.W., Stier A.C. and Silliman B.R., 2011. The value of estuarine and coastal ecosystem services. Ecol. Monogr., 81, 169-193.

Baumard P., Budzinski H. and Garrigues P., 1998. Polycyclic aromatic hydrocarbons in sediments and mussels of the western Mediterranean sea. Environ. Toxicol. Chem., 17, 765-776.

Béjaoui B., Harzallah A., Moussa M., Chapelle A. and Solidoro C., 2008. Analysis of hydrobiological pattern in the Bizerte lagoon (Tunisia). Estuar. Coast. Shelf Sci., 80, 121-129.

Ben Said O., Goni-Urriza M., El Bour M., Aissa P. and Duran R., 2010. Bacterial community structure of sediments of the Bizerte lagoon (Tunisia), a southern mediterranean coastal anthropized lagoon. Microb. Ecol., 59, 445-456.

Berns A.E., Philipp H., Narres H.D., Burauel P., Vereecken H. and Tappe W., 2008. Effect of gammasterilization and autoclaving on soil organic matter structure as studied by solid state NMR, UV and fluorescence spectroscopy. Eur. J. Soil Sci., 59, 540-550.

Cantwell M.G., Burgess R.M. and Kester D.R., 2002. Release and phase partitioning of metals from anoxic estuarine sediments during periods of simulated resuspension. Environ. Sci. Technol., 36, 5328-5334.

Chakraborty P., Babu P.V.R., Acharyya T. and Bandyopadhyay D., 2010. Stress and toxicity of biologically important transition metals (Co, $\mathrm{Ni}, \mathrm{Cu}$ and $\mathrm{Zn}$ ) on phytoplankton in a tropical freshwater system: An investigation with pigment analysis by HPLC. Chemosphere, 80, 548-553.

Cheung Y.H., Neller A., Chu K.H., Tam N.F.Y., Wong C.K., Wong Y.S. and Wong M.H., 1997. Assessment of sediment toxicity using different trophic organisms. Arch. Environ. Con. Tox., 32, 260-267.

Costanza R., d'Arge R., de Groot R., Farber S., Grasso M., Hannon B., Limburg K., Naeem S., O'Neill R.V., Paruelo J., Raskin R.G., Sutton P. and van den Belt M., 1997. The value of the world's ecosystem services and natural capital. Nature, 387, 253-260.

Cotner J.B., Johengen T.H. and Biddanda B.A., 2000. Intense winter heterotrophic production stimulated by benthic resuspension. Limnol. Oceanogr., 45, 1672-1676.

Crain C.M., Kroeker K. and Halpern B.S., 2008. Interactive and cumulative effects of multiple human stressors in marine systems. Ecol. Lett., 11, 1304-1315. 
Darling E.S. and Côté I.M., 2008. Quantifying the evidence for ecological synergies. Ecol. Lett., 11, 1278-1286.

Day K.E., Kirby R.S. and Reynoldson T.B., 1995. The effect of manipulations of fresh-water sediments on responses of benthic invertebrates in whole-sediment toxicity tests. Environ. Toxicol. Chem., 14, 1333-1343.

de la Broise D. and Palenik B., 2007. Immersed in situ microcosms: A tool for the assessment of pollution impact on phytoplankton. J. Exp. Mar. Biol. Ecol., 341, 274-281.

Derouiche A., Sanda Y.G. and Driss M.R., 2004. Polychlorinated biphenyls in sediments from Bizerte Lagoon, Tunisia. B. Environ. Contam. Tox., 73, 810-817.

Dodds W.K. and Cole J.J., 2007. Expanding the concept of trophic state in aquatic ecosystems: It's not just the autotrophs. Aquat. Sci., 69, 427-439.

Folt C.L., Chen C.Y., Moore M.V. and Burnaford J., 1999. Synergism and antagonism among multiple stressors. Limnol. Oceanogr., 44, 864-877.

Geffard O., Budzinski H. and His E., 2002. The effects of elutriates from PAH and heavy metal polluted sediments on Crassostrea gigas (Thunberg) embryogenesis, larval growth and bio-accumulation by the larvae of pollutants from sedimentary origin. Ecotoxicology, 11, 403-416.

Halpern B.S., Walbridge S., Selkoe K.A., Kappel C.V., Micheli F., D’Agrosa C., Bruno J.F., Casey K.S., Ebert C., Fox H.E., Fujita R., Heinemann D., Lenihan H.S., Madin E.M.P., Perry M.T., Selig E.R., Spalding M., Steneck R. and Watson R., 2008. A global map of human impact on marine ecosystems. Science, 319, 948-952.

Harzallah A., 2002. Etat actuel et évolution de l'exploitation halieutique et aquacole des lagunes - Cas de la lagune de Bizerte, Rapport de I'Institut National des Sciences et Technologie de la Mer, 128 p.

Hjorth M., Forbes V.E. and Dahllof I., 2008. Plankton stress responses from PAH exposure and nutrient enrichment. Mar. Ecol. Prog. Ser., 363, 121-130.

Kalnejais L.H., Martin W.R. and Bothner M.H., 2010. The release of dissolved nutrients and metals from coastal sediments due to resuspension. Mar. Chem., 121, 224-235.

Lawrence D., Dagg M.J., Liu H.B., Cummings S.R., Ortner P.B. and Kelble C., 2004. Wind events and benthic-pelagic coupling in a shallow subtropical bay in Florida. Mar. Ecol. Prog. Ser., 266, 1-13.

Legendre P. and Legendre L., 2012. Numerical ecology, 3rd edition, Elsevier, Amsterdam, 1006 p.

Liu X.H. and Huang W.R., 2009. Modeling sediment resuspension and transport induced by storm wind in Apalachicola Bay, USA. Environ. Modell. Softw., 24, 1302-1313.

Lund J.W.G., Kipling C. and Le Cren E.D., 1958. The inverted microscope method of estimating algal numbers and the statistical basis of estimations by counting. Hydrobiologia, 11, 143-170.

Martinez M.L., Intralawan A., Vazquez G., Perez-Maqueo O., Sutton P. and Landgrave R., 2007. The coasts of our world: Ecological, economic and social importance. Ecol. Econ., 63, 254-272.

Morin J. and Morse J.W., 1999. Ammonium release from resuspended sediments in the Laguna Madre estuary. Mar. Chem., 65, 97-110.

Mucha A.P., Leal M.F., Bordalo A.A. and Vasconcelos M.T., 2003. Comparison of the response of three microalgae species exposed to elutriates of estuarine sediments based on growth and chemical speciation. Environ. Toxicol. Chem., 22, 576-585.

Mzoughi N., Lespes G., Bravo M., Dachraoui M. and Potin-Gautier M., 2005. Organotin speciation in Bizerte lagoon (Tunisia). Sci. Total Environ., 349, 211-222.

Nayar S., Goh B.P. and Chou L.M., 2004. Environmental impact of heavy metals from dredged and resuspended sediments on phytoplankton and bacteria assessed in in situ mesocosms. Ecotox. Environ. Safe., 59, 349-369.

O'Gorman E.J., Fitch J.E. and Crowe T.P., 2012. Multiple anthropogenic stressors and the structural properties of food webs. Ecology, 93, 441-448.

Ouakad M., 2007. Genèse et évolution des milieux laguno-lacustres du Nord-Est de la Tunisie (Garaet el Ichkeul, Lagunes de Bizerte et Ghar el Mehl), Thèse d'état es Sciences Géologiques, Faculté des Sciences de Tunis, $461 \mathrm{p}$.

Pringault O., Tassas V. and Rochelle-Newall E., 2007. Consequences of respiration in the light on the determination of production in pelagic systems. Biogeosciences, 4, 105-114.

Pringault O., Tesson S. and Rochelle-Newall E., 2009. Respiration in the light and bacteriophytoplankton coupling in a coastal environment. Microb. Ecol., 57, 321-334. 
Raven J.A., Evans M.C.W. and Korb R.E., 1999. The role of trace metals in photosynthetic electron transport in $\mathrm{O}_{2}$-evolving organisms. Photosynth. Res., 60, 111-149.

Riedel G.F., Sanders J.G. and Breitburg D.L., 2003. Seasonal variability in response of estuarine phytoplankton communities to stress: Linkages between toxic trace elements and nutrient enrichment. Estuaries, 26, 323-338.

Ritchie R.J., 2008. Universal chlorophyll equations for estimating chlorophylls a, b, c, and d and total chlorophylls in natural assemblages of photosynthetic organisms using acetone, methanol, or ethanol solvents. Photosynthetica, 46, 115-126.

Roberts D.A., 2012. Causes and ecological effects of resuspended contaminated sediments (RCS) in marine environments. Environ. Int., 40, 230-243.

Rochelle-Newall E.J., Delesalle B., Mari X., Rouchon C., Torreton J.P. and Pringault O., 2008. Zinc induces shifts in microbial carbon flux in tropical coastal environments. Aquat. Microb. Ecol., 52, $57-68$.

Sahraoui I., Sakka Hlaili A., Mabrouk H.H., Leger C. and Bates S.S., 2009. Blooms of the diatom genus Pseudo-Nitzschia H. Peragallo in Bizerte lagoon (Tunisia, Sw Mediterranean). Diatom Res., 24, 175-190.

Sahraoui I., Grami B., Bates S.S., Bouchouicha D., Chikhaoui M.A., Mabrouk H.H. and Sakka Hlaili A., 2012. Response of potentially toxic Pseudo-nitzschia (Bacillariophyceae) populations and domoic acid to environmental conditions in a eutrophied, SW Mediterranean coastal lagoon (Tunisia). Estuar. Coast. Shelf Sci., 102, 95-104.

Sakka Hlaili A., Grami B., Mabrouk H.H., Gosselin M. and Hamel D., 2007. Phytoplankton growth and microzooplankton grazing rates in a restricted Mediterranean lagoon (Bizerte Lagoon, Tunisia). Mar. Biol., 151, 767-783.

Sundback K., Alsterberg C. and Larson F., 2010. Effects of multiple stressors on marine shallow-water sediments: Response of microalgae and meiofauna to nutrient-toxicant exposure. J. Exp. Mar. Biol. Ecol., 388, 39-50.

Torres M.A., Barros M.P., Campos S.C.G., Pinto E., Rajamani S., Sayre R. T. and Colepicolo P., 2008. Biochemical biomarkers in algae and marine pollution: A review. Ecotox. Environ. Safe., 71, 1-15.

Trabelsi S. and Driss M.R., 2005. Polycyclic aromatic hydrocarbons in superficial coastal sediments from Bizerte Lagoon, Tunisia. Mar. Pollut. Bull., 50, 344-348.

Trevors J.T., 1996. Sterilization and inhibition of microbial activity in soil. J. Microbiol. Meth., 26, 53-59.

Utermöhl H., 1958. Zur vervollkommnung der quantitativen phytoplankton-methodik, mitteilungen internationale vereinigung theorie angewandte. Limnologie, 9, 1-38.

Yoshida M, Hamdi H., Nasser I.A. and Jedidi N., 2002. Contamination of potentially toxic elements (PTEs) in Bizerte lagoon bottom sediments, surface sediment and sediment repository. RPPSEPMCL Initial Report, 13-48. 